\title{
The Spatial Distribution of Spanish Transport Infrastructure between 1860 and 1930
}

\author{
Alfonso Herranz-Loncán* \\ Department of Economic History and Institutions \\ University of Barcelona \\ Diagonal, 690 \\ Barcelona, Spain 08034 \\ Fax.: +34-93-402-4594. \\ Email: alfonso.herranz@ub.edu
}

\begin{abstract}
The origin of Spanish regional economic divergence can be traced back at least until the seventeenth century, although its full definition took place during industrialisation. Historians have often included uneven regional infrastructure endowments among the factors that explain divergence among Spanish regions, although no systematic analysis of the spatial distribution of Spanish infrastructure and its determinants has been carried out so far. This paper aims at filling that gap, by offering a description of the regional distribution of the main Spanish transport infrastructure between the middle of the nineteenth century and the Civil War. In addition, it estimates a panel data model to search into the main reasons that explain the differences among the Spanish regional endowments of railways and roads during that period. The outcomes of that analysis indicate that both institutional factors and the physical characteristics of each area had a strong influence on the distribution of transport infrastructure among the Spanish regions.
\end{abstract}

JEL Classfication: H54, L92, N73, O18

\footnotetext{
${ }^{*}$ I thank the financial support provided by the Spanish Ministry of Education Grant SEJ2005-02498 and the Bank of Spain. I gratefully acknowledge comments by participants in the University of Barcelona Economics Seminar, the III Barcelona Workshop in Economic Geography and the VIII Conference of the Spanish Economic History Association. I am particularly indebted to Dudley Baines, Nicholas Crafts, Jordi Pons, Leandro Prados de la Escosura, Max-Stephan Schulze and Carles Sudrià. This implies no responsibility on their part for the shortcomings that may remain in the paper.
} 


\section{Introduction}

The Spanish economy is nowadays characterised by huge differences in income per capita among regions. Although their origin may be traced back at least to the second half of the seventeenth century, ${ }^{1}$ the modern Spanish regional economic structure was not completely defined until the nineteenth and early twentieth centuries, when the process of regional divergence and geographical concentration of income substantially accelerated. As a result of that divergence, two different areas may be distinguished in the country. Since the beginning of the twentieth century, regional indicators of income per capita, degree of industrialization or physical quality-of-life reflect a division of the country between a rich "North" (made up by most Northern and Mediterranean regions and Madrid), which has enjoyed an intense development process during the nineteenth and twentieth centuries, and a poor "South" (Andalusia, Extremadura, Castile-La Mancha, Murcia and the Canary Islands), which has remained relatively stagnant or has experienced a gradual economic decline in relative terms. Some regions are difficult to classify within this structure, such as the largest and most heterogeneous ones (e.g. Castile-Leon, Aragon or Andalusia), or Galicia and Asturias, which had during the second half of the nineteenth century high indices of quality of life and low levels of income per capita in relative terms. However, in spite of that complexity, the existence of a fundamental geographical dualism in the Spanish economy during the last two centuries is broadly confirmed by the available information. $^{2}$

\section{Figure 1 about here}

The reasons for that regional divergence are complex. The literature on Early Modern Spain has stressed the importance of the differences in population density that resulted

\footnotetext{
${ }^{1}$ Llopis (2001), p. 523.

${ }^{2}$ The main regional economic variables for nineteenth and twentieth century Spain may be seen in Zapata (2001).
} 
from the Christian conquest of each region during the Middle Ages. ${ }^{3}$ The most sparselypopulated areas of the interior of the country initiated in the mid-seventeenth century a process of extensive agrarian growth without productivity increases, based on the colonisation of empty lands. By contrast, at the same time, some densely populated peripheral regions, especially on the Mediterranean coast, started a process of intensification of agriculture with a much greater impact on productivity. ${ }^{4}$ Those differences, which arouse in Early Modern times, tended to be reinforced later on, in a typical cumulative process based on the opportunities to exploit agglomeration and scale economies that were opened up to the regions with initial advantages. As a consequence, Spanish industrialisation was accompanied by the concentration of manufacturing in a few regions. ${ }^{5}$ Since income data are not available at the provincial level for the period of analysis, Table 1 illustrates this divergence process with information on the concentration of industry at the NUTS-III level (provinces) between the mid-nineteenth century and 1929.

\section{Table 1 about here}

In this context, historians have often pointed out that, from the early-nineteenth century onwards, a number of additional factors, such as technological change or economic policy, might have altered some of the previous regional advantages that were associated with population density. Among those aspects, the geographical pattern of Spanish infrastructure has often been mentioned as a potential factor of regional divergence during the nineteenth and early twentieth centuries. On the one hand, some regional analyses have stressed that the local development of some regions might have been hindered by the

\footnotetext{
${ }^{3}$ According to Llopis (2001), pp. 514-515, the main reasons for the differences in regional population density in the eighteenth century were the timing of the Christian conquest and the different control that the upper classes exerted on the colonisation process in each region after the conquest.

${ }^{4}$ Ibid., pp. 516-522. Other factors such as institutions, the geographic situation of each region, and the previous existence of market traditions were also relevant in the process of regional divergence since 1650 .

${ }^{5}$ Tirado et al. (2002), Rosés (2003) and Paluzie et al. (2004).
} 
shortage of transport networks. This might have happened, for instance, in Asturias, Galicia or the Pyrenees area. By contrast, other regions might have enjoyed a situation of abundant infrastructure from a comparative point of view, such as the Basque Country, Madrid, Cantabria or the central provinces of Castile-Leon. ${ }^{6}$ On the other hand, the spatial structure of the national transport and communication networks has been described as inefficient by some historians. More concretely, the radial shape of the Spanish road, railway and telegraph systems, which was mainly inspired by administrative criteria, might have made connections between production and consumption centres expensive. ${ }^{7}$ In addition, the Spanish government has been highly criticized for the impact that local lobbies and electoral strategies had on the spatial allocation of transport infrastructure among regions. ${ }^{8}$

This paper analyses the regional distribution of Spanish railways and roads between the mid-nineteenth century and the Civil War, as well as its main determinants, in order to observe if, in the global context of long-term Spanish regional divergence, some areas could have enjoyed situations of relative advantage or disadvantage regarding infrastructure, which could in turn have improved or worsened their growth prospects. The networks of railways and roads have been chosen as the object of study, since they constituted the core of the Spanish economic infrastructure during the period under consideration, accounting for 65 to 90 per cent of the total stock. In addition, they constituted by far the most important basis of market integration in Spain, because harsh geography prevented the development of inland waterways in the country. ${ }^{9}$ The paper is organised as follows. Section 2 offers a short description of the geographical distribution of

\footnotetext{
${ }^{6}$ For regional cases, see German et al (2001).

${ }^{7}$ See, for instance, Nadal (1975), pp. 48-50.

${ }^{8}$ Alzola (1979), pp. 437-438.

${ }^{9}$ See Herranz-Loncán (2005). The length of waterways in Spain was ca. $700 \mathrm{~km}$., which had a marginal role in the Spanish transportation system during the period under analysis.
} 
the networks of railways and roads during the period under study. In Section 3 an econometric exercise is carried out that tries to identify the main determinants of the spatial distribution of those two networks. Section 4 summarises the conclusions of the paper.

\section{The geographical distribution of Spanish railways and roads}

The comparison among infrastructure endowments of different regions requires an appropriate index of the actual service capacity of each type of infrastructure in each spatial context. In the case of large-scale transport and communication infrastructure, which can be characterised as "space-serving" assets, network density (i.e. the ratio between network length and the surface of the service area) probably constitutes the best available measure of service capacity. Increases in network density are the most direct way to reduce transport and communication costs, both through reductions in the average distance from each production or consumption point to the network and through decreases in the average detour of paths through the network.

Table 2 displays the evolution of the concentration of Spanish railway and road density among provinces between 1860 and 1930, and Figures 2 to 7 show the level of network density in each province in the years 1870, 1900 and 1930. As may be seen in the table, infrastructure distribution among the Spanish provinces was very uneven, being the level of endowment inequality much higher than in other European countries at the time, ${ }^{10}$ although in the case of roads the degree of concentration gradually decreased with the completion of the network. On the other hand, the maps show the high density of transport networks both in the Mediterranean coast and in the provinces situated in the centralNorthern area of Spain. At the other end of the range, Extremadura, Aragon, the SouthEast, the Canary Islands and most provinces of both Castiles were poorly endowed during

\footnotetext{
${ }^{10}$ For instance, in France, a country that is comparable to Spain in size, the coefficient of variation of the railway density of the départements was $40 \%$ in 1907 , whereas among the Spanish provinces it was $71 \%$ at that time. Data on France in Price (1983), pp. 222-223; the département of Seine (i.e. the city of Paris) has been excluded from the calculation to keep the coefficients comparable.
} 
the whole period under study. In a mid position, Western Andalusia and Galicia were well endowed with one type of infrastructure (railways in Andalusia and roads in Galicia) but poorly endowed with the other.

\section{Table 2 about here}

Figures 2 to 7 about here

Density figures should be compared with regional needs for infrastructure in order to draw conclusions about the relative infrastructure shortage in each area. A very preliminary indicator of regional needs is given by population density. Figure 8 compares a weighted (normalised) average of the railway and road network density figures with population density in each region. ${ }^{11}$

\section{Figure 8 about here}

Although the coefficients of correlation between both magnitudes were positive throughout the period ( 0.45 in $1870,0.64$ in 1900 and 0.65 in 1930), the graphs allow observing some situations of relative infrastructure shortage or abundance, which are consistent with some regional historians' hypotheses. More concretely, some Northern areas, such as Cantabria, Navarre or Castile-Leon, would have enjoyed a situation of relative advantage, whereas Asturias, Galicia, the Canary Islands, the Valencian Community and, in the first decades of the twentieth century, Madrid, would have suffered from a situation of relative infrastructure shortage. ${ }^{12}$ These examples seem to indicate that the regional distribution of infrastructure was not just a reflection of long-term differences among the Spanish regional economies, but it instead responded to other circumstances and, therefore, might have been a potential factor of regional divergence in the Spanish economy, as historians have often

\footnotetext{
${ }^{11}$ The weights that have been used to calculate the average transport network density are the relative importance of railways and roads within Spanish total capital stock in each date, taken from Herranz-Loncán (2005).

${ }^{12}$ In the case of Madrid, however, the extremely high spatial concentration of the population in the capital city makes the comparison with other areas difficult.
} 
indicated. The next section aims at analysing the main determinants of the actual provincial distribution of the railways and roads during the late nineteenth and early twentieth centuries.

\section{An explanatory model for the provincial distribution of Spanish railways and roads}

\subsection{The model}

This section is based on previous research by Rietveld and Boonstra (1995) and Rietveld and Wintershoven (1998) on the factors that explain the current distribution of railways and highways among the EU regions. This section includes a similar estimation exercise for the Spanish railway and road networks during the period 1860-1930, although the paucity of quantitative information has made some adjustments necessary.

For the sake of clarity, those authors divide the determinants of regional endowments of transport infrastructure into "demand" and "supply" factors. From the "demand" point of view, construction of infrastructure is said to respond to the perceived need for infrastructure services or, in other words, to the ex ante expected level of use of the networks. A region's need for transport infrastructure would depend, firstly, on population density. Transport infrastructure endowment is expected to grow with population density, although at a decreasing rate, for two reasons. On the one hand, beyond a certain saturation point, incorporation of new lines to the networks may no longer be functional. And, on the other hand, the indivisible character of most large-scale transport infrastructure necessarily produces some excess endowment in sparsely-populated areas. Secondly, the structure of the system of population centres also affects the level of expected traffic of transport links. If population is highly concentrated in a small number of large cities, traffic will be concentrated on a few routes, but if the same population is highly dispersed, traffic will also be diverted to many different links and, as a consequence, the construction of expensive transport infrastructure may not be justified on cost-benefit grounds. 
Thirdly, income per capita raises the demand for transport in several ways, e.g. by increasing the share of market-orientated activities, the specialisation and concentration of production, or the purchasing power of individuals. Fourthly, the structure of production also determines a region's transport needs, because some activities are more transport intensive than others. Finally, the expected use of infrastructure also depends on the level of interregional transport demand. Some routes may cross an area just to connect two foreign regions, without meeting any internal need. Accordingly, international borders and the sea may reduce the demand for infrastructure in a region, because they diminish the potential number of interregional links that might cross the area.

From the "supply" point of view, the regional cost of infrastructure construction, which depends on the geographical characteristics of each area (i.e. its topographical difficulty) and on the price of immobile resources, will also influence the level of investment. Secondly, infrastructure "supply" also depends on the financial capacity of the potential investors. In the case of a purely private investment, capital mobility across regions may minimise the importance of this factor but, in the case of public or subsidised investment, the financial capacity of the public institutions which are in charge of either the investment or the subsidy may set a budget constraint on the process of construction. As a consequence, broad differences in the investment capacity of different regions may arise due to such factors as the institutional framework or the level of income per capita of each region, which would determine regional tax returns. Finally, Rietveld and Boonstra (1995) and Rietveld and Wintershoven (1998) also include, among the "supply" factors, the possibility of the objective function of the public sector to include non-efficiency objectives, such as equity or the short-term stimulation of stagnant regional economies.

\subsection{The data}


Information on the aforementioned variables has been searched for the Spanish provinces in the first year of each decade between 1860 and 1930, although in some cases it has been difficult to find a suitable indicator. Regarding regional transport "demand", data on provincial population density and the degree of urbanisation and industrialisation have been collected. ${ }^{13}$ As no reliable provincial estimates of income per capita are available for the period under study, urbanisation and industrialisation rates are taken here as secondbest indicators of the Spanish provinces' level of development. However, the interpretation of these two variables is complex, because the rate of urban population is also an indirect indicator of the size and structure of population centres, and the level of provincial industrialisation may also affect the demand for transport services because some sectors are more transport-intensive than others.

Regarding "supply" factors, differences in the cost of infrastructure construction among provinces have been approached through the information on "third-category" road construction costs in each province. ${ }^{14}$ As for the financial capacity of local investors, it has only been possible to take into account the particular fiscal situation of the Basque Country and Navarre. ${ }^{15}$ Those areas benefited from a great fiscal autonomy, as their provincial governments were responsible for the management of the whole tax system within the

\footnotetext{
${ }^{13}$ Data on demographic density, urbanization, and the share of industrial active population come from the available population censuses. These refer to the years 1860, 1877, 1887, 1900, 1910, 1920 and 1930; in this context, data for 1880 and 1890 have been taken from the 1877 and 1887 censuses, respectively, and, for 1870, a geometric interpolation of the 1860 and 1877 figures has been calculated. I have considered population as urban in municipalities with 10,000 or more people. Luna (1988) warns that, in some cases, the census data for some large municipalities do not correspond to real urban towns but to the administrative aggregation of several small villages. In order to make up for this problem, she excludes from urban population those municipalities that lacked a significant number of high buildings, or which included more than ten population centers, or whose main center was smaller than 5,000 people. This procedure has also been followed here.

${ }^{14}$ Information available in Memoria(s), Anuario(s), and Estadística(s) de Obras Públicas for most years between 1873 and 1924. Unfortunately, these figures exclude Navarre and the Basque Country, where the main roads were not constructed by the central government but by the provincial institutions (Diputaciones). In those cases, the construction cost levels of similar contiguous provinces have been applied.

${ }^{15}$ Information on provincial and local public institutions' budgets is only available for the period before 1886 and for a few years between 1917 and 1927, in the Spanish Statistical Yearbooks and Reseña Geográfica y Estadística de España.
} 
territory under their administration. The central government only took part in the process as the passive recipient of a previously established yearly amount of money. According to the available data and some contemporary opinions, such a system enormously improved the financial situation of the provincial and local public institutions of those provinces, compared with the rest of the country. ${ }^{16}$

Finally, still from the "supply" point of view, the presence of investment objectives different from pure efficiency, such as equity, the administrative and political unification of the country, the influence of lobbies or electoral considerations, were very relevant in the construction of Spanish large transport networks. In particular, the successive Railway Acts reflected the government's wish to connect all Spanish provinces to the network, which may be understand as a means to promote national unification, facilitate the dispatch of troops and military supplies, and control information and the movement of people and goods. ${ }^{17}$ However, in an aggregate analysis it is virtually impossible to measure deviations of public policy from geographically optimal investment criteria and, as a consequence, some unexplained residual of the provincial distribution of investment would be related to the potential uneven distribution of those deviations among the Spanish provinces.

As a first approach to the relationship between infrastructure density and its potential determinants, Table 3 compares the relative endowment of railways and roads at the NUTS-II level ("Comunidades Autónomas") with the main characteristics of each region at three points of time. ${ }^{18}$ The different areas are arranged according to their average transport network density. The correlation coefficients between each variable and the endowment of railways and roads, which are presented in the last two rows of the table,

\footnotetext{
${ }^{16}$ Alzola (1979), p. 41. This opinion seems to be confirmed by the information available on provincial and local institutions' budgets (see below, Table 3).

${ }^{17}$ See Alzola (1979) and, on a general basis, Millward (2004).

${ }^{18}$ Some of the variables in Table 3 have not been used in the estimation because either they are not available at the provincial level, or they are not available for the whole period or for all the provinces.
} 
indicate that the correlation between the railway endowment of each area and its main economic characteristics was high during the whole period under study, with the only exception of the rate of urbanisation. By contrast, the distribution pattern of the road network was rather independent from most economic variables at the beginning of the period and only gradually converged with population density and the industrialisation level although, similar to railways, it remained unrelated to regional figures of urbanisation.

\section{Table 3 about here}

\section{Outcomes of the estimation}

The model that has been presented above has been applied to the geographical distribution of Spanish railways and roads throughout the period 1860-1930, on the basis of the pool of cross-section and time-series data that has just been described. All variables are measured at the provincial (NUTS-III) level and in the first year of each decade. The model is estimated for the whole railway and road systems, and also for their main components, i.e. broad and narrow gauge railways, and central government and local and provincial roads. All specifications include population density and its square, to account for the fact that infrastructure density is expected to increase at a decreasing rate with population density. Unit construction cost is also included in all cases, as well as a dummy variable that reflects the particular fiscal situation of the Basque Country and Navarre. In order to account for the hypothetical influence of interregional demand, a spatial autoregresive model has been incorporated in the specification. As is customary in this sort of exercises, the spatial AR model has been specified as:

$A y=X \beta+\varepsilon$

$A=I-\gamma W$

where $\mathrm{W}$ is a "rowsum=1 standardised" weight matrix that reflects the spatial structure of the data. In this case, the entries of $\mathrm{W}$ equal 1 if two provinces are contiguous and 0 
otherwise. In the same vein, two additional dummy variables have been included that take the value 1 in coastal and border provinces, respectively, and the value 0 otherwise. Finally, given the large number of provinces compared with the short number of time periods, no individual effects have been incorporated in the model, and the individual residuals have been assumed to be randomly distributed. Otherwise, the number of parameters to estimate would have grown disproportionately. The outcomes of the estimation are shown in Tables 4 and 5. Estimates in Tables 4 and 5 are two-stage-least squares, which are robust to the presence of cross-section heteroskedasticity. Time lags of the potentially endogenous right-hand variables (population density and urbanisation and industrialisation rates) and the rest of the explanatory variables have been taken as instruments.

\section{Tables 4 and 5 about here}

Regarding the hypotheses of the model, the outcomes of the estimation are mixed. Firstly, in virtually all cases (with the exception of narrow gauge railways) provincial endowments of transport networks increased with population density and, in most cases, they did so at a decreasing rate. Secondly, network density was denser in the most industrialised regions. Insofar as the level of industrialisation is a proxy for income per capita, this would confirm the existence of a direct relationship between economic growth and transport infrastructure endowment. Thirdly, the impact of urbanisation seems to have been different among networks. Whereas broad gauge railways were more abundant in urban areas, the density of both narrow gauge railways and roads was instead higher in the most rural areas of the country. The negative relationship between urbanisation and the provincial endowment of roads would reflect the public effort to bring the road network to the largest possible number of people. In those provinces where population was most disseminated, the government would have financed a rather dense road network just to serve the same share 
of population as in urban provinces. This situation was to be found particularly in some Northern areas of the country, such as Galicia, Asturias, Cantabria, the Basque Country or Navarre, where people used to live in relatively small centres. By contrast, no similar efforts to avoid situations of disadvantage in rural regions may be found in the case of the broad gauge railway network. In this case, the high construction cost of the main railways would have made the widespread extension of their service too expensive to be assumed by public or private investors. Only in the case of the narrow gauge lines, their lower construction cost as well as the mining character of many of them, seem to have allowed their extension through rural areas.

Regarding interregional demand, spatial spillovers are significant in all specifications. At the same time, closeness to the coast and the borders of the country discouraged the development of the road network, but stimulated the construction of railways. This would be an evidence of the specialisation of different networks in different kinds of traffic. Whereas nineteenth century European railways had a clearly international orientation and were complementary to long-distance navigation, the roads were mainly used for short and medium-distance traffic. As far as the presence of an international boundary or the sea are proxies for the importance of international transport demand in an area, this might explain the higher development of railways in coastal and border provinces. ${ }^{19}$

As for the "supply" variables, the coefficients of construction cost are negative and significant in all cases, as might be expected, whereas the coefficients of the fiscal dummy are positive in all cases, except for the central government roads. This exception is due to the fact that most roads in the Basque Country and Navarre, even in the case of the main network, were built by the Diputaciones and classified therefore as provincial.

\footnotetext{
${ }^{19}$ However, the inclusion in the model of an additional dummy variable with value 1 in provinces with port and value 0 otherwise does not yield significant results, due to the presence of active commercial ports in virtually all the coastal provinces during the period of analysis and its subsequent high collinearity with the sea dummy.
} 
To sum up, as far as the Spanish regional divergence is concerned, the geographical distribution of infrastructure seems to have been a reinforcing factor of previous economic differences among regions, since it responded to a large extent to the population density and the level of industrialisation of each region. However, some qualifications may be introduced within that broad picture. Firstly, some regions would have suffered the negative effect of a rough geography, as is indicated by the negative sign of the coefficients of construction costs. This would indeed be very relevant to explain the relative infrastructure deprivation of the North-West of the country (Galicia and Asturias) or the Canary Islands, where the density of the transport networks was always much lower in relative terms than population density. Secondly, the institutional setting of the country was also essential to explain regional infrastructure endowments. More concretely, the special fiscal situation of the Basque Country and Navarre was highly positive for the development of the transport network of those areas, which could always benefit from a relatively large endowment of railways and

roads in relative terms. And, finally, the government's wish to extend the road service to the highest possible share of population in each province would have turned the road network into a balancing factor during industrialisation since, ceteris paribus, it was much more dense in rural than in urban regions.

\section{Conclusions}

This article aims at explaining the determinants of the uneven availability of transport infrastructure among the Spanish regions before 1936. As could be expected, the outcomes of the analysis show that regional transport infrastructure endowments were largely adapted to population density and the level of industrialisation of each region, and constituted therefore a reinforcing factor of the existing economic divergence. However, there are also some indications of mismatch between economic development and infrastructure endowment that would indicate that infrastructure also had a role in the further definition of Spanish regional 
economic structure. Firstly, infrastructure investment clearly responded to the level of construction costs in each region, which might have hindered the growth prospects of areas with difficult topography. Secondly, the special institutional setting of the Basque Country and Navarre would have been a source of advantage for those two regions in terms of infrastructure investment. And, thirdly, the government's willingness to extend the road network to the maximum possible number of people made it to be much denser, ceteris paribus, in rural than in urban regions.

\section{References}

Alzola P (1979) [1899] Las obras públicas en España. Estudio histórico. Madrid, Colegio de Ingenieros de Caminos, Canales y Puertos.

Betrán C (1997) Geografía industrial en España durante el primer tercio del siglo XX. In La riqueza de las regiones. Análisis espacial de la industrialización, Proceedings of the 9th Session of the VI Congress of the Asociación Española de Historia Económica, Girona, 15-17 de septiembre: 65-84.

Germán L, Llopis E, Maluquer J and Zapata S (eds.) (2001) Historia económica regional de España, siglos XIX y XX. Barcelona, Crítica.

Herranz-Loncan A (2005) The Spanish Infrastructure Stock, 1844-1935. Research in Economic History 23: 85-129.

Llopis E (2001) El legado económico del Antiguo Régimen desde la óptica regional. In Germán L, Llopis E, Maluquer J and Zapata S (eds.) Historia económica regional de España, siglos XIX y XX. Barcelona, Crítica: 507-524.

Luna G (1988) La población urbana en España, 1860-1930. Boletín de la Asociación de Demografía Histórica 6: 25-68.

Millward R (2004). European Governments and the Infrastructure Industries, c. 1840-1914. European Review of Economic History 8: 3-28.

Ministerio de Obras Públicas (1940) Plan General de Obras Públicas. Madrid, Talleres Penitenciarios de Alcalá.

Nadal J (1975) El fracaso de la revolución industrial en España, 1814-1913. Barcelona, Ariel.

Paluzie E, Pons J and Tirado D A (2004) The geographical concentration of industry across Spanish regions, 1856-1995. Review of Regional Research 24: 143-160.

Price R (1983) The Modernization of Rural France: Communication Networks and Agricultural Market Structure in Nineteenth Century France. London, Hutchinson.

Reseña Geográfica y Estadística de España (1888). Madrid.

Rietveld P and Boonstra J (1995) On the supply of network infrastructure. Annals of Regional Science 29: 207-220.

Rietveld P and Wintershoven P (1998) Border Effects and Spatial Autocorrelation in the Supply of Network Infrastructure. Papers in Regional Science 77: 265-276.

Rosés J R (2003) Why Isn't the Whole of Spain Industrialized? New Economic Geography and Early Industrialization, 1797-1910. Journal of Economic History 63: 995-1022.

Tirado D A, Paluzie E and Pons J ( 2002) Economic Integration and Industrial Location: The Case of Spain Before World War I. Journal of Economic Geography 2: 343- 
363.

Zapata S (2001) Apéndice estadístico. In Germán L, Llopis E, Maluquer Jordi and Zapata $\mathrm{S}$ (eds.) Historia económica regional de España, siglos XIX y XX. Barcelona, Crítica: 561-596. 
Figure 1

\section{The Spanish regions (NUTS-II)}

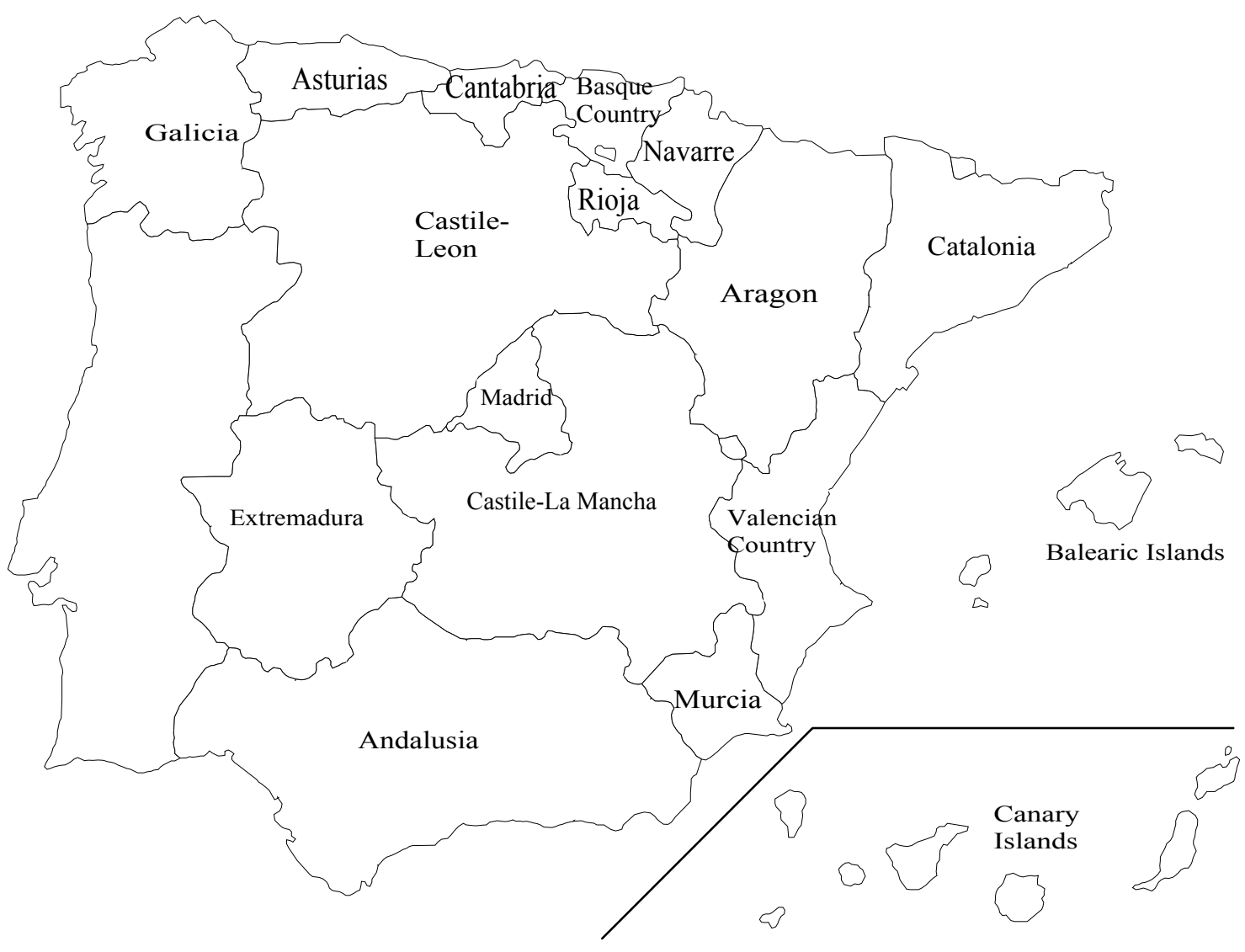


Figure 2

Railway density in the Spanish provinces in 1870

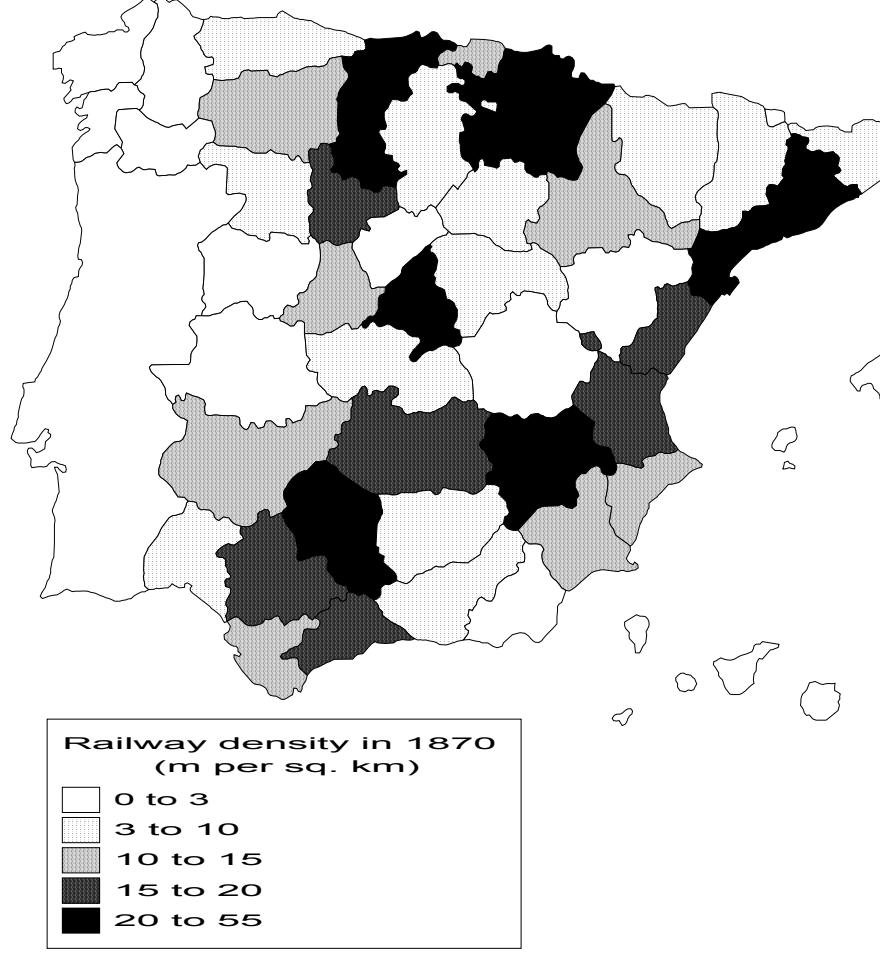


Figure 3

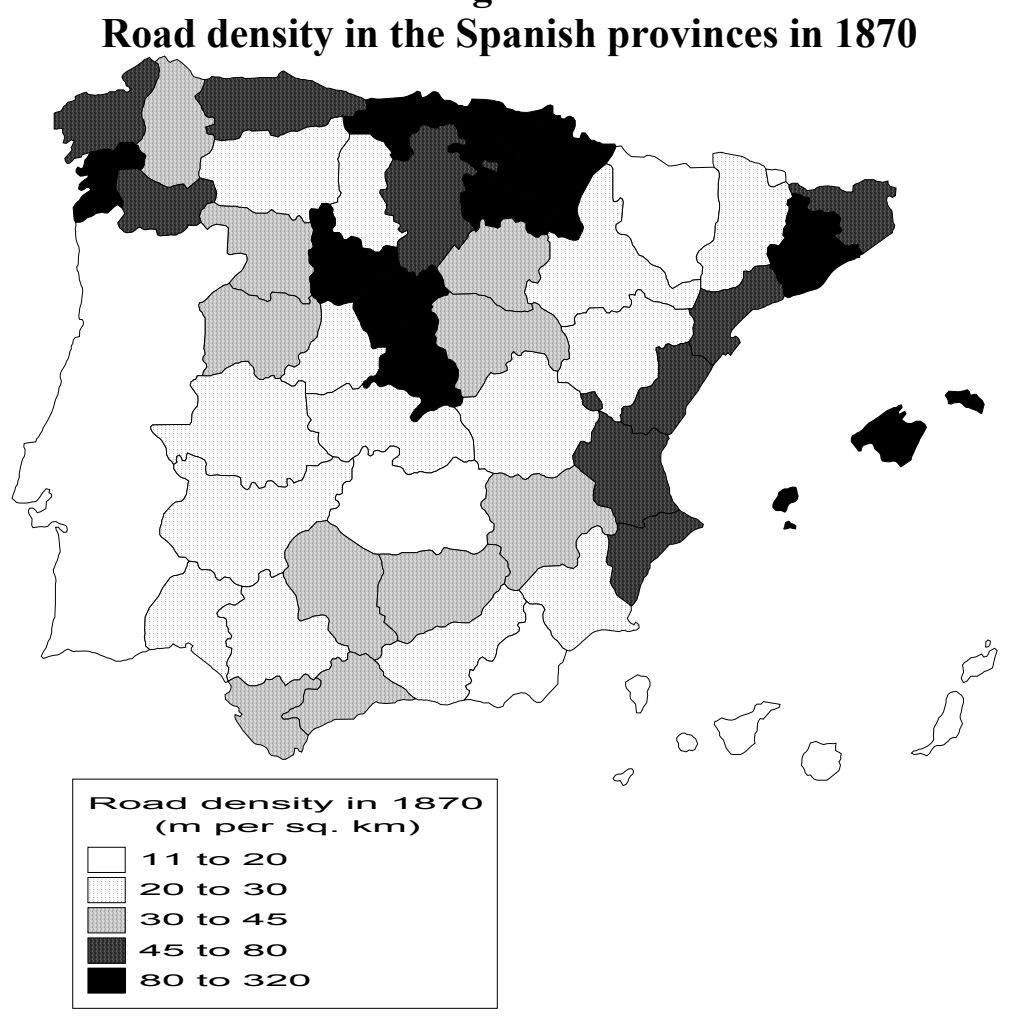


Figure 4

Railway density in the Spanish provinces in 1900

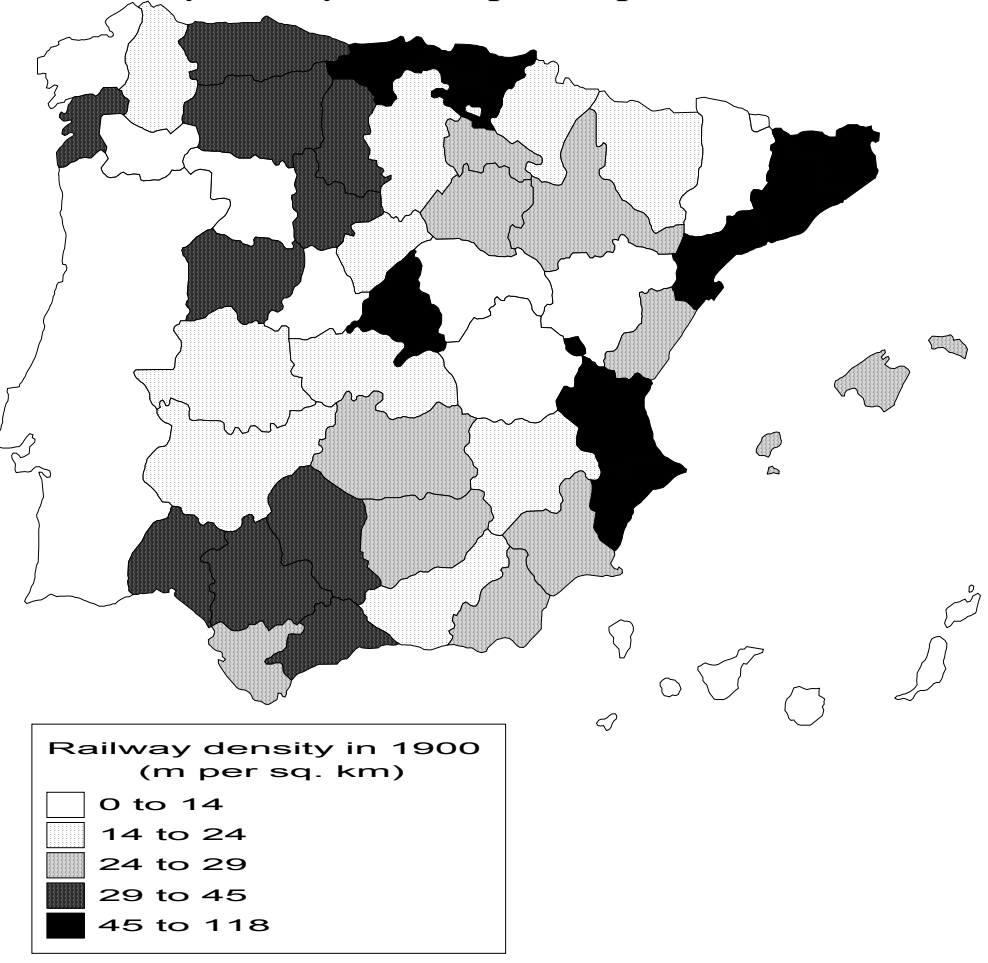


Figure 5

Road density in the Spanish provinces in 1900

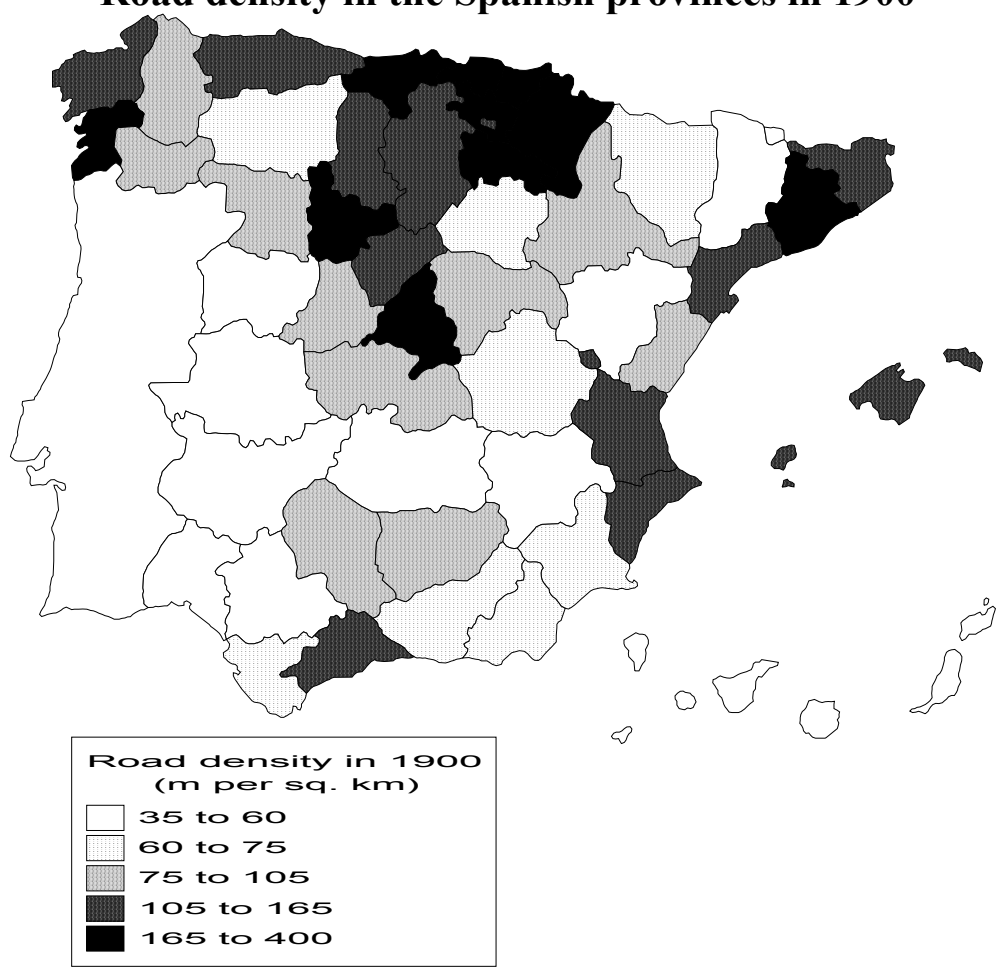


Figure 6

Railway density in the Spanish provinces in 1930

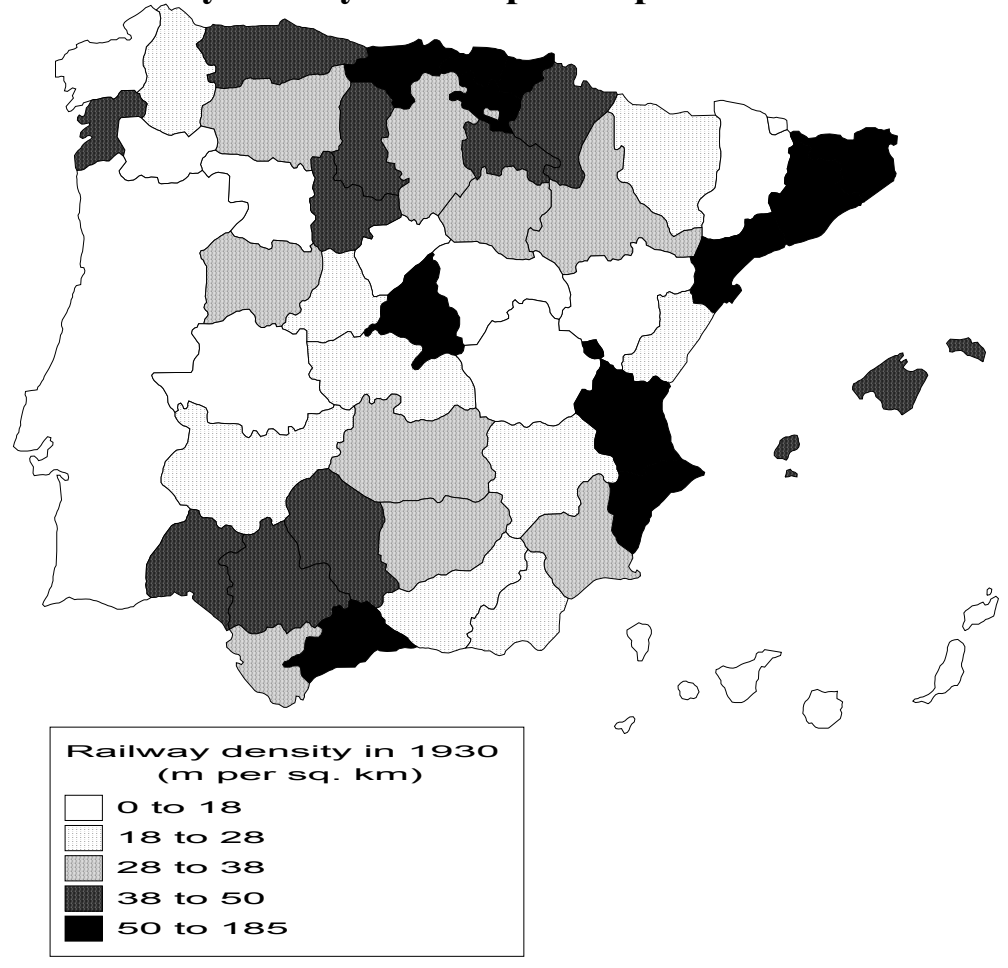


Figure 7

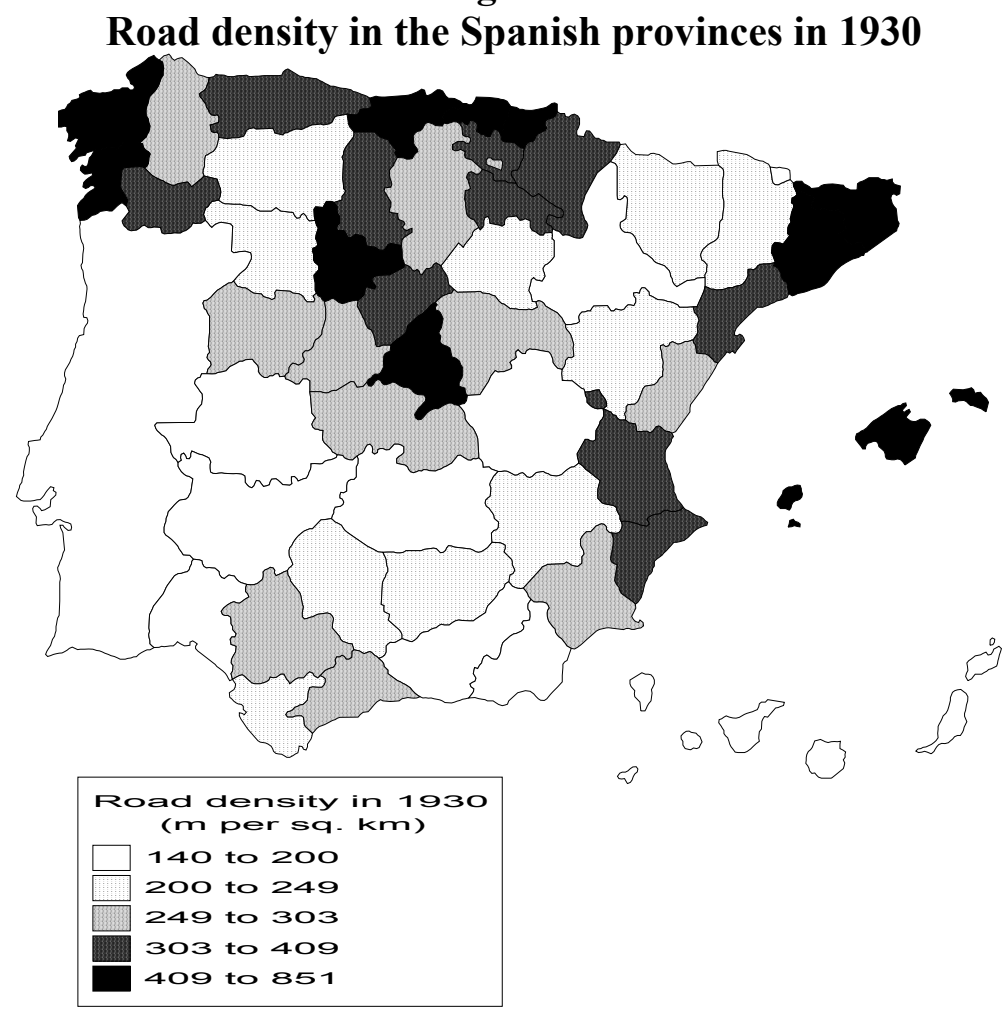

Sources and note to Figures 2 to 7: see Table 2. 
Figure 8

Transport networks and population density in the Spanish regions (NUTS-II)

A) 1870

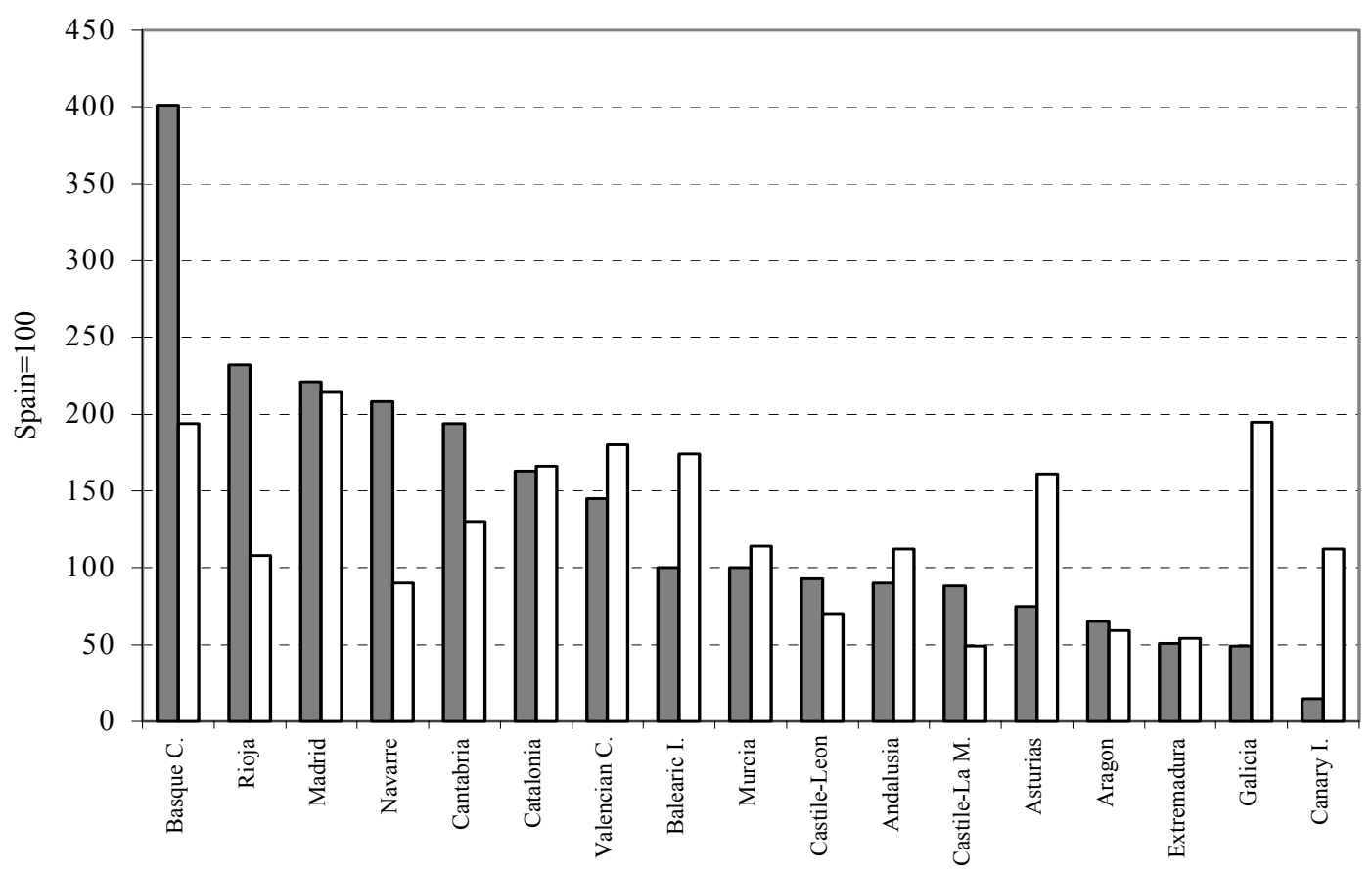

$\square$ Transport network density $\square$ Population density

B) 1900

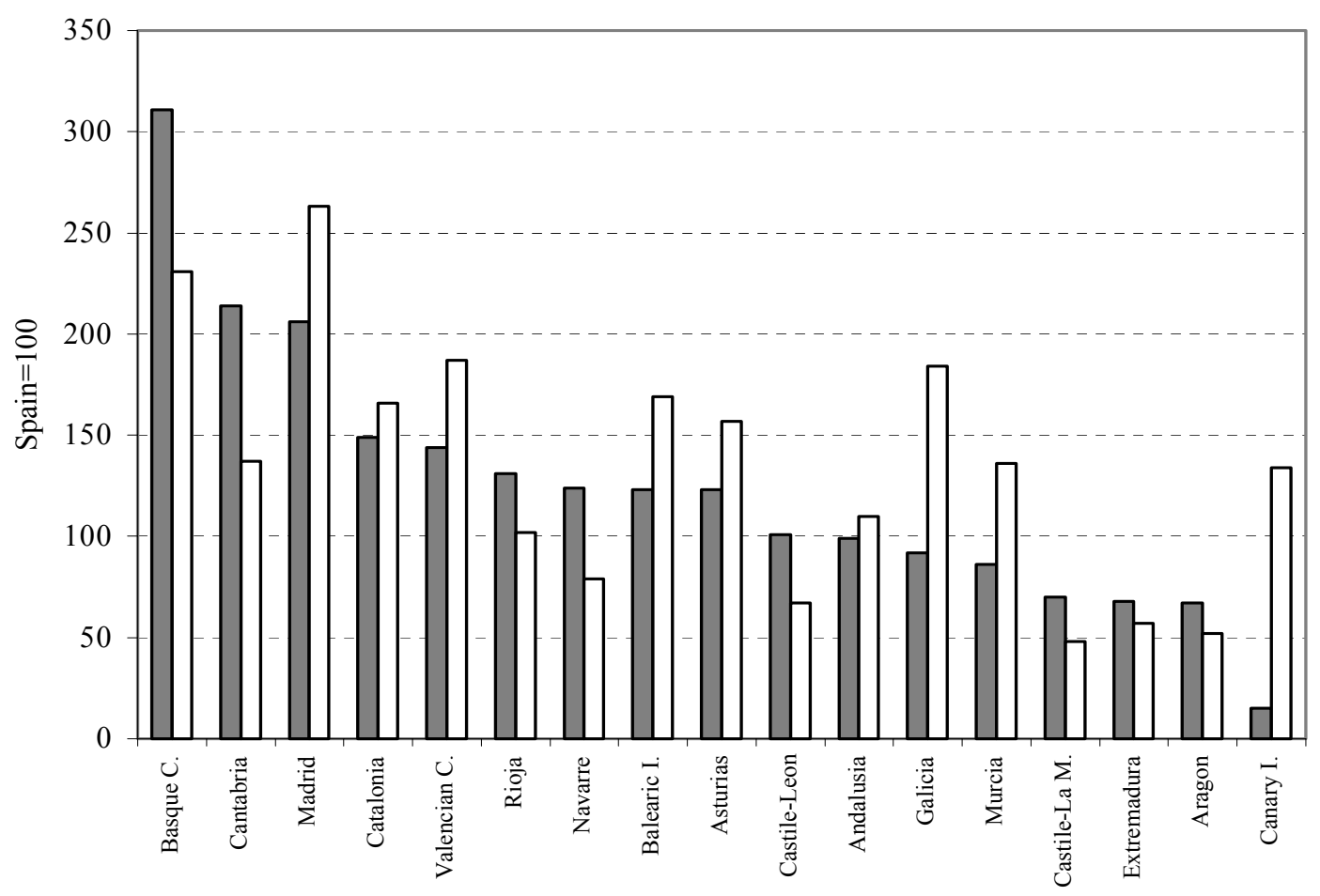

$\square$ Transport network density $\square$ Population density 


\section{C) 1930}

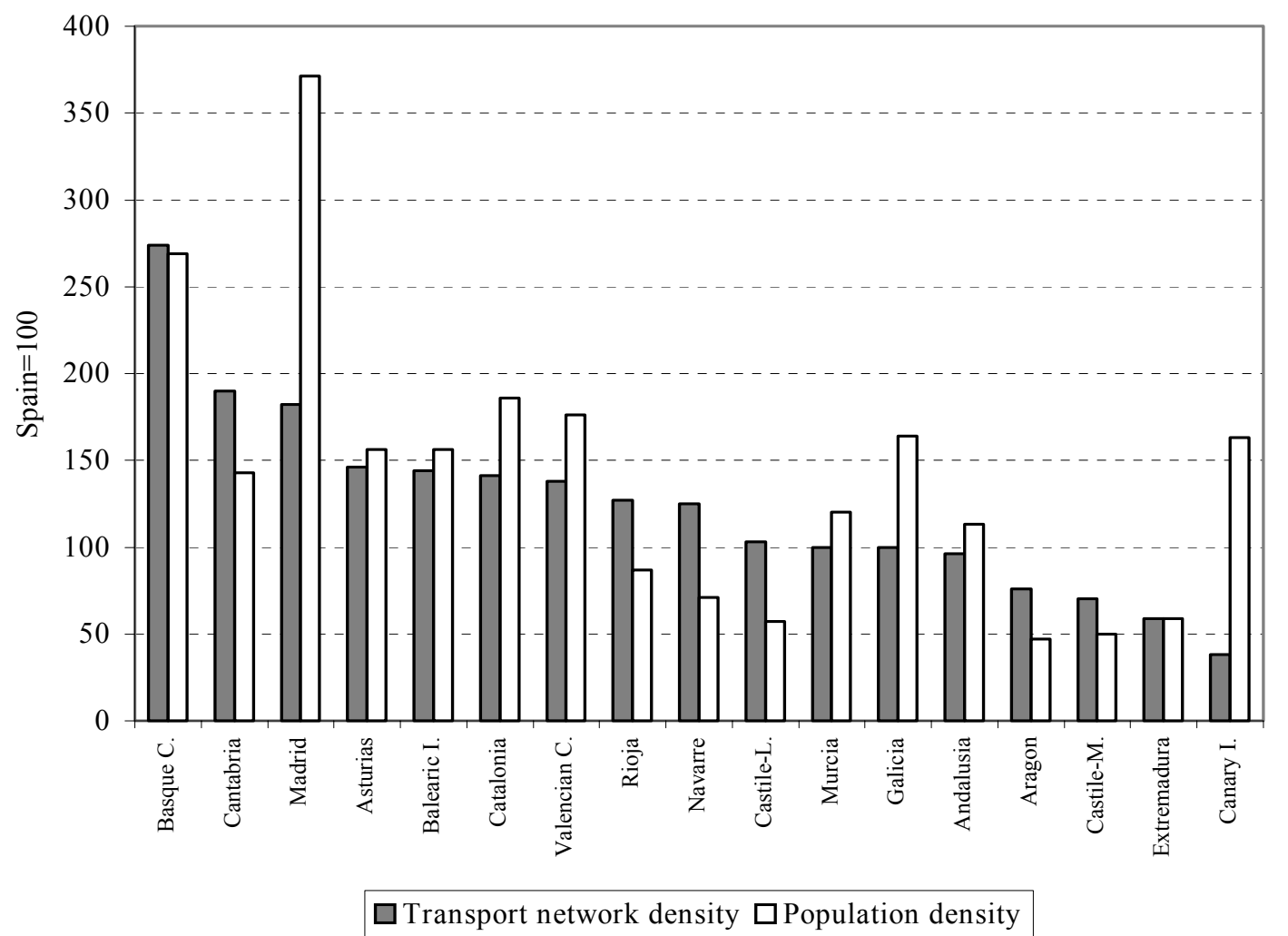

Source: For transport network density, see Table 2. For Population density, Spanish Population Censuses. 
Table 1. Concentration of industry among the Spanish provinces (NUTS-III) (coefficient of variation, \%).

\begin{tabular}{|l|c|c|c|c|c|c|c|}
\hline Year & 1856 & $1878-79$ & $1989-90$ & $1895-96$ & 1905 & 1913 & 1929 \\
\hline Coefficient of variation & 125.6 & 177.7 & 169.6 & 203.0 & 208.1 & 215.2 & 253.5 \\
\hline
\end{tabular}

Source: own calculation from Estadística Administrativa de la Contribución Industrial and Betrán (1997). Note: figures exclude the Basque Contry and Navarre between 1856 and 1905.

Table 2. Concentration of railway and road density among the Spanish provinces (NUTSIII) (coefficient of variation, \%).

\begin{tabular}{|l|c|c|c|c|c|c|c|}
\hline & 1870 & 1880 & 1890 & 1900 & 1910 & 1920 & 1930 \\
\hline Railway density & 94.3 & 72.9 & 72.0 & 72.3 & 71.3 & 75.6 & 76.6 \\
\hline Road density & 98.0 & 72.7 & 65.0 & 60.4 & 59.9 & 51.1 & 43.5 \\
\hline
\end{tabular}

Source: Railway density from Memoria(s), Anuario(s) and Estadística(s) de Obras Públicas and Anuario(s) de Ferrocarriles de D. Enrique de la Torre; road density from Memoria(s), Anuario(s) and Estadística(s) de Obras Públicas and Ministerio de Obras Públicas (1940), Vol. 1, pp. 200-201.

Note: For the first decades of the period under study, figures on provincial and local roads are not completely reliable, due to the lack of homogeneity in the statistical criteria that were followed in different provinces. 
Table 3. Infrastructure endowment and structural characteristics of the Spanish regions (NUTS-II).

\begin{tabular}{|c|c|c|c|c|c|c|c|c|c|}
\hline & $\begin{array}{c}\text { Railway } \\
\text { Density } \\
\text { Norm. }\end{array}$ & $\begin{array}{c}\text { Road } \\
\text { Density } \\
\text { Norm. }\end{array}$ & $\begin{array}{l}\text { Weigh. } \\
\text { average }\end{array}$ & $\begin{array}{c}\text { Pop. } \\
\text { density }^{1}\end{array}$ & $\begin{array}{l}\text { Urb. } \\
\text { rate } \\
(\%)^{1}\end{array}$ & $\begin{array}{l}\text { Industrial } \\
\text { tax p.c. }{ }^{2}\end{array}$ & $\begin{array}{l}\text { Ind. } \\
\text { A.P. } \\
(\%)^{3}\end{array}$ & $\begin{array}{c}\text { Fiscal } \\
\text { capacity } \\
\text { p.c. }^{4}\end{array}$ & $\begin{array}{l}\text { Unit } \\
\text { cost }\end{array}$ \\
\hline Basque C. & 325 & 543 & 401 & 62 & 15 & na & 22 & 19 & na \\
\hline Rioja & 245 & 209 & 232 & 35 & 7 & 117 & 14 & 9 & 112 \\
\hline Madrid & 241 & 185 & 221 & 69 & 66 & 129 & 21 & 27 & 74 \\
\hline Navarre & 194 & 234 & 208 & 29 & 10 & na & 12 & 13 & na \\
\hline Cantabria & 190 & 200 & 194 & 42 & 16 & 94 & 16 & 10 & 133 \\
\hline Catalonia & 182 & 129 & 163 & 53 & 31 & 272 & 29 & 11 & 141 \\
\hline Valencian C & 156 & 124 & 145 & 58 & 27 & 90 & 18 & 8 & 108 \\
\hline Balearic I. & 0 & 287 & 100 & 56 & 32 & 101 & 23 & 9 & 69 \\
\hline Murcia & 117 & 67 & 100 & 37 & 68 & 57 & 17 & 5 & 84 \\
\hline Castile-L. & 88 & 103 & 93 & 23 & 7 & 85 & 10 & 8 & 81 \\
\hline Andalusia & 103 & 66 & 90 & 36 & 39 & 95 & 20 & 10 & 113 \\
\hline Castile-M. & 102 & 63 & 88 & 16 & 8 & 73 & 11 & 8 & 64 \\
\hline Asturias & 33 & 154 & 75 & 52 & 11 & 56 & 7 & 4 & 184 \\
\hline Aragon & 71 & 54 & 65 & 19 & 11 & 68 & 13 & 9 & 102 \\
\hline Extremadura & 50 & 54 & 51 & 17 & 8 & 68 & 9 & 8 & 97 \\
\hline Galicia & 0 & 139 & 49 & 63 & 7 & 44 & 9 & 4 & 95 \\
\hline Canary I. & 0 & 43 & 15 & 36 & 12 & 13 & 11 & 4 & 166 \\
\hline SPAIN & 100 & 100 & 100 & 32 & 22 & 100 & 16 & 9 & 100 \\
\hline St Dev. (\%) & 77.79 & 78.73 & & 41.63 & 89.13 & 63.88 & 39.34 & 57.42 & 32.31 \\
\hline Correl RW & & & & 0.25 & 0.20 & 0.58 & 0.48 & 0.72 & -0.11 \\
\hline Correl R & & & & 0.52 & -0.05 & 0.31 & 0.39 & 0.53 & -0.09 \\
\hline
\end{tabular}

B) 1900

\begin{tabular}{|c|c|c|c|c|c|c|c|c|}
\hline & $\begin{array}{c}\text { Railway } \\
\text { Density } \\
\text { Norm. }\end{array}$ & $\begin{array}{l}\text { Road } \\
\text { Density } \\
\text { Norm. }\end{array}$ & $\begin{array}{l}\text { Weigh. } \\
\text { average }\end{array}$ & $\begin{array}{l}\text { Pop. } \\
\text { density }\end{array}$ & $\begin{array}{l}\text { Urb. } \\
\text { rate } \\
(\%)\end{array}$ & $\begin{array}{l}\text { Industrial } \\
\text { tax p.c. }{ }^{5}\end{array}$ & $\begin{array}{c}\text { Ind. A.P. } \\
(\%)\end{array}$ & Unit cost \\
\hline Basque C. & 324 & 291 & 311 & 85 & 29 & 491 & 35 & na \\
\hline Cantabria & 219 & 205 & 214 & 51 & 25 & 87 & 20 & 133 \\
\hline Madrid & 206 & 206 & 206 & 97 & 74 & 97 & 23 & 74 \\
\hline Catalonia & 160 & 132 & 149 & 61 & 41 & 300 & 27 & 141 \\
\hline Valencian C. & 162 & 114 & 144 & 69 & 37 & 85 & 16 & 108 \\
\hline Rioja & 101 & 180 & 131 & 38 & 10 & 86 & 16 & 112 \\
\hline Navarre & 87 & 184 & 124 & 29 & 9 & 80 & 11 & na \\
\hline Balearic I. & 91 & 174 & 123 & 62 & 34 & 46 & 22 & 69 \\
\hline Asturias & 109 & 147 & 123 & 58 & 15 & 84 & 14 & 184 \\
\hline Castile-L. & 97 & 107 & 101 & 25 & 9 & 44 & 9 & 81 \\
\hline Andalusia & 113 & 76 & 99 & 41 & 41 & 90 & 17 & 113 \\
\hline Galicia & 69 & 129 & 92 & 68 & 9 & 24 & 8 & 95 \\
\hline Murcia & 94 & 73 & 86 & 50 & 81 & 51 & 10 & 84 \\
\hline Castile-M. & 67 & 75 & 70 & 18 & 15 & 63 & 13 & 64 \\
\hline Extremadura & 75 & 57 & 68 & 21 & 16 & 43 & 11 & 97 \\
\hline Aragon & 62 & 74 & 67 & 19 & 15 & 54 & 13 & 102 \\
\hline Canary I. & 0 & 40 & 15 & 49 & 27 & 13 & 16 & 166 \\
\hline SPAIN & 100 & 100 & 100 & 37 & 29 & 100 & 16 & 100 \\
\hline St Dev. (\%) & 62.98 & 50.14 & & 46.76 & 75.28 & 115.39 & 42.78 & 32.31 \\
\hline Correl RW & & & & 0.63 & 0.30 & 0.79 & 0.77 & -0.03 \\
\hline Correl R & & & & 0.59 & 0.02 & 0.63 & 0.66 & -0.02 \\
\hline
\end{tabular}




\begin{tabular}{|c|c|c|c|c|c|c|c|c|c|}
\hline & $\begin{array}{c}\text { Railway } \\
\text { Density } \\
\text { Norm. }\end{array}$ & $\begin{array}{c}\text { Road } \\
\text { Density } \\
\text { Norm. }\end{array}$ & $\begin{array}{l}\text { Weigh. } \\
\text { average }\end{array}$ & $\begin{array}{l}\text { Pop. } \\
\text { density }\end{array}$ & $\begin{array}{l}\text { Urb. } \\
\text { rate } \\
(\%)\end{array}$ & $\begin{array}{l}\text { Industrial } \\
\text { tax p.c. }{ }^{6}\end{array}$ & $\begin{array}{l}\text { Ind. } \\
\text { A.P. } \\
(\%)\end{array}$ & $\begin{array}{c}\text { Fiscal } \\
\text { capacity } \\
\text { p.c. }{ }^{7} \\
\end{array}$ & $\begin{array}{l}\text { Unit } \\
\text { cost }\end{array}$ \\
\hline Basque C. & 344 & 207 & 274 & 126 & 45 & 291 & 51 & na & na \\
\hline Cantabria & 199 & 181 & 190 & 67 & 31 & 162 & 40 & 95 & 133 \\
\hline Madrid & 201 & 163 & 182 & 173 & 81 & 174 & 51 & 214 & 74 \\
\hline Asturias & 148 & 144 & 146 & 73 & 19 & 108 & 46 & 82 & 184 \\
\hline Balearic I. & 135 & 152 & 144 & 73 & 42 & 52 & 37 & 76 & 69 \\
\hline Catalonia & 154 & 129 & 141 & 87 & 54 & 322 & 50 & 175 & 141 \\
\hline Valencian C. & 154 & 123 & 138 & 82 & 44 & 88 & 35 & 96 & 108 \\
\hline Rioja & 121 & 132 & 127 & 40 & 23 & 116 & 32 & 106 & 112 \\
\hline Navarre & 123 & 127 & 125 & 33 & 15 & 74 & 21 & na & na \\
\hline Castile-M. & 60 & 107 & 103 & 26 & 23 & 27 & 25 & 69 & 64 \\
\hline Murcia & 92 & 108 & 100 & 56 & 80 & 30 & 32 & 71 & 84 \\
\hline Galicia & 63 & 135 & 100 & 77 & 12 & 17 & 26 & 52 & 95 \\
\hline Andalusia & 110 & 82 & 96 & 53 & 50 & 51 & 27 & 90 & 113 \\
\hline Aragon & 77 & 76 & 76 & 22 & 21 & 115 & 31 & 100 & 102 \\
\hline Castile-L. & 98 & 80 & 70 & 23 & 13 & 34 & 27 & 88 & 81 \\
\hline Extremadura & 60 & 59 & 59 & 28 & 26 & 20 & 28 & 73 & 97 \\
\hline Canary I. & 0 & 74 & 38 & 76 & 33 & 15 & 49 & na & 166 \\
\hline SPAIN & 100 & 100 & 100 & 47 & 38 & 100 & 34 & 96 & 100 \\
\hline St Dev. (\%) & 60.85 & 32.42 & & 60.18 & 58.90 & 92.50 & 28.49 & 43.88 & 31.35 \\
\hline Correl RW & & & & 0.61 & 0.34 & 0.78 & 0.52 & 0.65 & 0.02 \\
\hline Correl R & & & & 0.66 & 0.29 & 0.62 & 0.43 & 0.33 & 0.06 \\
\hline
\end{tabular}

Railway Density Norm: railway density $\left(\mathrm{m}\right.$ per $\left.\mathrm{km}^{2}\right)$, normalised by the Spanish average. Road Density Norm: road density $\left(\mathrm{m}\right.$ per $\left.\mathrm{km}^{2}\right)$, normalised by the Spanish average.

Ind. A.P.: share of male active population engaged in the secondary sector.

Fiscal capacity p.c.: total expenses of local and provincial public institutions per capita (pesetas).

Unit cost: average of the normalised road construction costs of the provinces within each region.

Correl RW and R: correlation coefficient between each variable and railway and road density, respectively.

Notes: na: not available; (1) population figures for 1870 are obtained by geometrical interpolation of data from the 1860 and 1877 censuses; (2) industrial fiscal returns in 1870 are obtained by geometrical interpolation of data on 1856 and 1878/1879; (3) in 1877; (4) in 1865/66; (5) for 1900, industrial tax information is completed with Parejo's estimates for the Basque Country and Navarre (see Zapata (2001), p. 579); (6) in 1929; (7) in 1927.

Sources: for railway and road density see Table 2; population density and urbanisation rate from population censuses and Luna (1988); industrial tax per capita from Estadistica(s) Administrativa(s) de la Contribución Industrial, Zapata (2001), p. 579, and Betrán (1997); industrial active population from Zapata (2001), p. 568; local and provincial fiscal capacity from Spanish Statistical Yearbooks; unit construction cost from Memoria(s), Anuario(s) and Estadística(s) de Obras Públicas. 
Table 4. The determinants of the provincial distribution of Spanish railways

\begin{tabular}{|c|c|c|c|}
\hline Variable & $\begin{array}{c}\text { Total } \\
\text { Network }\end{array}$ & $\begin{array}{c}\text { Broad } \\
\text { Gauge } \\
\text { Railways }\end{array}$ & $\begin{array}{c}\text { Narrow } \\
\text { Gauge } \\
\text { Railways }\end{array}$ \\
\hline Constant & $\begin{array}{c}-0.372 \\
(-0.139)\end{array}$ & $\begin{array}{l}4.119 * \\
(2.168)\end{array}$ & $\begin{array}{l}-2.228 * * \\
(-3.060)\end{array}$ \\
\hline Population density & $\begin{array}{l}0.187 * * \\
(3.088)\end{array}$ & $0.261^{* *}$ & $\begin{array}{c}-0.016 \\
(-0.265)\end{array}$ \\
\hline Population density sq. & $\begin{array}{l}0.0001 \\
(0.167)\end{array}$ & $(-0.116)$ & $(2.236)$ \\
\hline Urbanisation rate & $\begin{array}{l}0.159^{* *} \\
(3.626)\end{array}$ & $0.134^{* *}$ & $\left(-0.017^{*}\right.$ \\
\hline Industrial active population. & $0.126^{* *}$ & $0.039^{* *}$ & $0.023^{* *}$ \\
\hline Construction cost & $-0.106^{* *}$ & $-0.087 * *$ & $(-2.220)$ \\
\hline Fiscal dummy & $\begin{array}{c}15.397 * * \\
(2.924)\end{array}$ & $\begin{array}{c}1.073 \\
(0.379) \\
\end{array}$ & $\begin{array}{r}5.306 \\
(0.574) \\
\end{array}$ \\
\hline $\begin{array}{l}\text { Railway density in contiguous } \\
\text { provinces }\end{array}$ & $\begin{array}{c}0.507^{* *} \\
(7.885)\end{array}$ & $\begin{array}{c}0.506^{* *} \\
(7.640)\end{array}$ & $\begin{array}{l}0.657 * * \\
(20.525)\end{array}$ \\
\hline Sea & $(2.184)$ & $\begin{array}{l}-2.489^{*} \\
(-2.475)\end{array}$ & $3.492 * *$ \\
\hline Border & $\begin{array}{l}2.895^{*} \\
(2.084) \\
\end{array}$ & $\begin{array}{l}3.608^{* *} \\
(4.281) \\
\end{array}$ & $\begin{array}{c}0.075 \\
(0.658) \\
\end{array}$ \\
\hline $\begin{array}{l}\text { Adj } R^{2} \\
T \\
\text { No of observations }\end{array}$ & $\begin{array}{c}0.68 \\
5 \\
245 \\
\end{array}$ & $\begin{array}{c}0.93 \\
5 \\
245 \\
\end{array}$ & $\begin{array}{c}0.51 \\
5 \\
245 \\
\end{array}$ \\
\hline
\end{tabular}

Notes: t-ratios in brackets; $* 5$ per cent significance level; $* * 1$ per cent significance level.

Table 5. The determinants of the provincial distribution of Spanish roads

\begin{tabular}{|c|c|c|c|}
\hline Variable & $\begin{array}{c}\text { Total } \\
\text { Network }\end{array}$ & $\begin{array}{c}\text { Central } \\
\text { Government } \\
\text { Roads }\end{array}$ & $\begin{array}{c}\text { Provincial } \\
\text { and Local } \\
\text { Roads }\end{array}$ \\
\hline Constant & $\begin{array}{c}9.990 \\
(1.895)\end{array}$ & $\begin{array}{c}6.576 \\
(1.410)\end{array}$ & $\begin{array}{c}-3.923 \\
(-1.294)\end{array}$ \\
\hline Population density & $\begin{array}{l}2.207 * * \\
(12.152)\end{array}$ & $\begin{array}{l}1.598^{* *} \\
(15.175)\end{array}$ & $\begin{array}{l}0.420^{* *} \\
(3.582)\end{array}$ \\
\hline Population density sq. & $\begin{array}{l}-0.005^{* *} \\
(-3.827)\end{array}$ & $\begin{array}{l}-0.005^{* *} \\
(-8.937)\end{array}$ & $\begin{array}{c}0.001 \\
(1.570)\end{array}$ \\
\hline Urbanisation rate & $\left(-0.656^{* *}\right.$ & $\begin{array}{l}-0.462^{* *} \\
(-8.971)\end{array}$ & $\begin{array}{r}0.020 \\
(0.456)\end{array}$ \\
\hline Industrial active population. & $0.115^{* *}$ & $\begin{array}{l}0.026 \\
(1.076)\end{array}$ & $\begin{array}{c}0.038 \\
(1.591)\end{array}$ \\
\hline Construction cost & $\begin{array}{l}-0.368 * * \\
(-7.625)\end{array}$ & $\begin{array}{l}-0.149^{* *} \\
(-3.076)\end{array}$ & $\begin{array}{l}-0.085 * * \\
(-3.537)\end{array}$ \\
\hline Fiscal dummy & $\begin{array}{c}40.733^{* *} \\
(7.136)\end{array}$ & $\begin{array}{l}-62.908^{* *} \\
(-21.155)\end{array}$ & $\begin{array}{c}139.115^{* *} \\
(9.702)\end{array}$ \\
\hline $\begin{array}{l}\text { Road density in contiguous } \\
\text { provinces }\end{array}$ & $\begin{array}{l}0.664 * * \\
(63.364)\end{array}$ & $\begin{array}{l}0.690^{* *} \\
(40.158)\end{array}$ & $\begin{array}{l}0.420^{* *} \\
(19.305)\end{array}$ \\
\hline Sea & $\begin{array}{c}-10.086^{* *} \\
(-2.892)\end{array}$ & $\begin{array}{l}-7.378 \\
(-1.907)\end{array}$ & $\begin{array}{l}-3.153 \\
(-1.323)\end{array}$ \\
\hline Border & $\begin{array}{c}-14.520^{* *} \\
(-8.827)\end{array}$ & $\begin{array}{c}-12.740^{* *} \\
(-9.515)\end{array}$ & $\begin{array}{l}-4.435^{* *} \\
(-4.049)\end{array}$ \\
\hline $\begin{array}{l}\text { Adj } \mathrm{R}^{2} \\
\mathrm{~T} \\
\text { No of observations }\end{array}$ & $\begin{array}{c}0.97 \\
5 \\
245\end{array}$ & $\begin{array}{c}0.96 \\
5 \\
245\end{array}$ & $\begin{array}{c}0.81 \\
5 \\
245\end{array}$ \\
\hline
\end{tabular}

Notes: t-ratios in brackets; $* 5$ per cent significance level; $* * 1$ per cent significance level 